\title{
A MODIFIED WINGATE TEST FOR MEASURING ANAEROBIC WORK OF THE UPPER BODY IN JUNIOR ROWERS
}

\author{
Y. KOUTEDAKIS, BA, MA and N. C. C. SHARP, BVMS, MRCVS, PhD
}

Department of Physical Education and Sports Science, University of Birmingham

\begin{abstract}
Eight elite junior oarsmen (ER) and sixteen club level rowers (CR) were tested for upper body strength (trunk, arms) and for mean, peak and minimum power outputs using the Double-Arm Anaerobic Work Test (DAAWT). This test is a modified version of the original Wingate test whereby athletes can be tested using trunk and both arms simultaneously. Multiple Discriminant Analysis was used to determine if the DAAWT variables alone were sensitive enough to discriminate between the two groups. Additionally, Pearson's correlation coefficients and ANOVA were employed. Results indicate that mean power and power difference expressed in absolute values (Watts) could successfully classify junior oarsmen into appropriate groups $(91.8 \%, P<0.001)$. In addition, there was a fairly high correlation $(r=0.81)$ between mean power and strength in the ER. The strongest ER demonstrated the least fatigue while highly significant differences between the groups in most of the other variables examined have also been demonstrated.
\end{abstract}

Key words: Junior oarsmen, DAAWT, Mean power, Peak power, Minimum power, Upper body strength, Fatigue.

\section{INTRODUCTION}

As a competitive sport, rowing is considered to be one of the most physically demanding (Secher, 1983). Rowers derive their energy requirements from both aerobic and anaerobic metabolism, the ratio of which depends on parameters of the sport, such as number of athletes in the boat, skill level, race distance, and, therefore, race duration. Muscular energy from anaerobic sources would seem to play a vital role, especially at the start and the final sprint of a rowing race. Measurements regarding the effectiveness of rowers' aerobic metabolism have been conducted on candidates for various national and Olympic teams, and some physiological profiles of elite national men and women rowers have been established (Jackson and Secher, 1976; Hagerman et al, 1979; Secher et al, 1982; Hagerman and Staron, 1983; Mahler et al, 1983; Mahler et al, 1985). However, there are few studies on the anaerobic side of rowers, particularly juniors.

The Wingate Anaerobic Test (WAT), designed by Bar-Or and his colleagues (Bar-Or et al, 1977), is relatively easy to administer and has proved to be a very useful tool for testing aspects of muscular work in which the contribution of energy from anaerobic sources may be considered to be relatively high (Bar-Or, 1978; Bar-Or et al, 1977; Jacobs et al, 1983; Tamayo et al, 1984; Tharp et al, 1985). However, the conventional WAT does not permit the subject to work using arms or legs simultaneously, hence the authors felt it to be less valid for testing athletes in "simultaneous limb sports" such as rowing.

A computerised "double-arm" version of the WAT has been developed (Sharp et al, 1986) aiming to measure power outputs of subjects whose sport requires a simultaneous use of both arms. In this modified Double Arm Anaerobic Work Test (DAAWT), work is performed by using both arms to turn a bar connecting the cranks of two Monark cycle ergometers, with the subject sitting in a rowing position between them on an adjustable seat with a

Address for correspondence:

Dr. N. C. C. Sharp

Human Motor Performance Laboratory

Dept. of Physical Education and Sports Science

University of Birmingham

Birmingham B15 2TT footrest. The purpose of the present study, therefore, was to examine whether or not the DAAWT could be a source of meaningful data regarding the more anaerobic aspects of junior competitive rowers. Furthermore, an attempt has been made to compare scores obtained from the DAAWT with data from measures of upper body strength which are thought to be among the leading variables for predicting rowing performance (Hagerman, 1984; Secher, 1983).

\section{METHODS}

Twenty-four male junior rowers who divided into two groups, elite (ER) and club level rowers (CR), volunteered as subjects. The ER group were $17.6 \pm 0.7$ years old, $190.2 \pm$ $4.2 \mathrm{~cm}$ tall and weighed $83.1 \pm 4.3 \mathrm{~kg}$, compared with $17.3 \pm$ 0.6 years, $182.9 \pm 5.5 \mathrm{~cm}$ and $75.2 \pm 5.2 \mathrm{~kg}$ respectively for the CR. For the elite group eight members of the 1985 British and Greek National Squads were tested, among whom were four medallists and one finalist from the 1985 World Junior Championships. The remaining sixteen subjects were members of various top-class British rowing clubs. All the subjects were in excellent physical condition when studied, preparing for or just after major national or international competitions. The tests took place between 15 June 85 and 15 Sept. 85, as part of a comprehensive study concerning male junior rowers. The subjects were tested in groups of three or four, in the afternoons, with the order of testing presented below.

The percentage of body fat was estimated from the measurement of skinfold thickness (Durnin and Rahaman, 1967). Maximum isometric strength of the upper body (trunk, and arms) was assessed using strain gauge techniques. The subjects sat on a specially designed bench, with their legs straight and placed against a foot rest. They were instructed to pull maximally, using trunk and arms simultaneously, on a wooden handle connected to the strain gauges, following the command "go". The best of three attempts was recorded.

The protocol for the DAAWT has been reported elsewhere (Sharp et al, 1986). The only modification was in the resistance used. Indeed, it has been suggested (Dotan and Bar-Or, 1983) that work load is a modifiable feature depending, particularly, on the individual's anaerobic fitness. Thus, a pilot study prior to the tests revealed the most appropriate resistance for the DAAWT for rowers to be 
$8 \%$ of their body weight. To ensure a maximal effort, the test was always conducted with the entire group present to provide encouragement throughout the $\mathbf{3 0}$ seconds of the test. Five indices were measured, namely;

Peak Power - the peak level of work performed during any successive 5-second period.

Time to Peak Power - this usually occurred within the first ten seconds.

Anaerobic Capacity - the mean work performed during the 30-second test.

Minimum Power - the lowest work performed during the test.

Power Difference - the difference between the highest and lowest power outputs recorded. This may also more usefully be expressed as a percentage fall-off. Four indices were expressed in absolute and relative values, i.e. Watts and Watts per $\mathrm{kg}$ body weight $\left(\mathrm{W} \cdot \mathrm{kg}^{-1}\right)$, and the time to peak power was measured in seconds.
The SPSS system subprogrammes (Nie et al, 1975) were used to obtain Pearson's correlation coefficients and ANOVA to determine relationships and differences between selected variables. Discriminant Analysis was also applied to determine whether variables from the DAAWT alone were sensitive enough to differentiate the two groups and to classify the subjects into the appropriate group. Differences and correlation coefficients were considered significant if $p<0.05$.

\section{RESULTS}

The means, standard deviations and ranges for each variable are given in Table I, while zero order correlations between selected variables are presented in Tables II and III. In many cases the latter tables, two parameters have a fairly high correlation, but when the data were normalised for body weight the relationships become weaker. Table IV shows the differences between the two groups of rowers

TABLE I

Test results for elite rowers $(E R, n=8)$ and club rowers $(C R, n=16)$

\begin{tabular}{|c|c|c|c|c|c|c|c|c|c|c|c|}
\hline Groups & Statistics & $\begin{array}{c}\text { Body Fat } \\
(\%)\end{array}$ & $\begin{array}{l}\text { Upper Body } \\
\text { Strength } \\
\text { (kg) }\end{array}$ & $\begin{array}{c}\text { Mean Power } \\
\text { (W) }\end{array}$ & $\begin{array}{c}\text { Peak Power } \\
\text { (W) }\end{array}$ & $\begin{array}{l}\text { Min. Power } \\
\text { (W) }\end{array}$ & $\begin{array}{l}\text { Power } \\
\text { Differ. } \\
\text { (W) }\end{array}$ & $\begin{array}{l}\text { Mean Power } \\
\left(W \cdot \mathbf{k g}^{-1}\right)\end{array}$ & $\begin{array}{l}\text { Peak Power } \\
\left(W \cdot \mathbf{k g}^{-1}\right)\end{array}$ & $\begin{array}{c}\text { Min. Power } \\
\left(W \cdot \mathbf{k g}^{-1}\right)\end{array}$ & $\begin{array}{c}\text { Power } \\
\text { Decline } \\
(\%)\end{array}$ \\
\hline \multirow[t]{3}{*}{ ER } & $\overline{\mathbf{x}}$ & 13.7 & 177.0 & 849.37 & 979.50 & 691.37 & 296.87 & 10.22 & 11.77 & 8.12 & 30.50 \\
\hline & SD & 2.2 & 13.81 & 67.66 & 73.61 & 116.51 & 45.66 & 0.48 & 0.45 & 0.84 & 6.14 \\
\hline & Range & $10-16$ & $166-209$ & $746-946$ & $885-1127$ & $542-912$ & $240-365$ & $9.6-11$ & $11.1-12.5$ & $6.9-9.5$ & $23-29$ \\
\hline \multirow[t]{3}{*}{ CR } & $\overline{\mathbf{x}}$ & 15.2 & 144.62 & 610.18 & 716.37 & 492.75 & 211.12 & 8.10 & 9.51 & 6.59 & 29.56 \\
\hline & SD & 2.8 & 10.75 & 69.26 & 80.26 & 62.65 & 45.08 & 0.71 & 0.78 & 0.76 & 5.75 \\
\hline & Range & $11-20$ & $128-162$ & $497-762$ & $630-876$ & $392-608$ & $119-298$ & $6.7-9.3$ & $7.7-10.7$ & $5.3-7.6$ & $18-43$ \\
\hline
\end{tabular}

$E R=$ Elite Rowers

CR = Club level Rowers

TABLE II

Zero Order Correlation Coefficients between Variables in this Study, Elite Junior Rowers $(\mathbf{n}=\mathbf{8}$ )

\begin{tabular}{|c|c|c|c|c|c|c|c|c|c|}
\hline Variables & 1 & 2 & 3 & 4 & 5 & 6 & 7 & 8 & 9 \\
\hline $\begin{array}{l}\text { 1. Upper Body } \\
\text { Strength } \\
\text { (kg) }\end{array}$ & 1.00 & & & & & & & & . \\
\hline $\begin{array}{l}\text { 2. Mean Power } \\
\text { (W) }\end{array}$ & $\begin{array}{c}0.81 \\
p=0.007\end{array}$ & 1.00 & & & & & & & \\
\hline $\begin{array}{l}\text { 4. Minimum } \\
\text { Power } \\
\text { (W) }\end{array}$ & $p=0.05$ & $\begin{array}{c}0.93 \\
p=0.001\end{array}$ & $p=0.94$ & 1.00 & & & & & \\
\hline $\begin{array}{l}\text { 5. Power } \\
\text { Difference } \\
\text { (W) }\end{array}$ & $\begin{array}{r}-0.64 \\
p=0.04\end{array}$ & $\begin{array}{r}-0.73 \\
p=0.02\end{array}$ & $\begin{array}{c}-0.44 \\
\text { NS }\end{array}$ & $\begin{array}{r}-0.69 \\
p=0.02\end{array}$ & 1.00 & & & & \\
\hline $\begin{array}{l}\text { 7. Peak Power } \\
\left(W \cdot \mathbf{k g}^{-1}\right)\end{array}$ & $\begin{array}{l}0.30 \\
\text { NS }\end{array}$ & $\begin{array}{l}0.60 \\
\text { NS }\end{array}$ & $\begin{array}{r}0.74 \\
p=0.01\end{array}$ & $\begin{array}{l}0.59 \\
\text { NS }\end{array}$ & $\begin{array}{l}0.01 \\
\text { NS }\end{array}$ & $p=\begin{array}{r}0.65 \\
p .03\end{array}$ & 1.00 & & \\
\hline $\begin{array}{l}\text { 8. Minimum } \\
\text { Power } \\
\left(W \cdot \mathbf{k g}^{-1}\right)\end{array}$ & $\begin{array}{r}0.70 \\
p=0.02\end{array}$ & $\begin{array}{c}0.96 \\
p=0.001\end{array}$ & $\begin{array}{c}0.88 \\
p=0.002\end{array}$ & $p=0.001$ & $\begin{array}{r}-0.69 \\
p=0.02\end{array}$ & $\begin{array}{r}0.73 \\
p=0.02\end{array}$ & $\begin{array}{r}0.68 \\
p=0.03\end{array}$ & 1.00 & \\
\hline $\begin{array}{l}\text { 9. Power } \\
\text { Decline } \\
\text { (\% of Peak P) }\end{array}$ & $\begin{array}{r}-0.71 \\
p=0.02\end{array}$ & $\begin{array}{c}-0.90 \\
p=0.001\end{array}$ & $\begin{array}{r}-0.71 \\
p=0.02\end{array}$ & $\begin{array}{c}-0.88 \\
p=0.002\end{array}$ & $p=0.94$ & $\begin{array}{c}-0.56 \\
\text { NS }\end{array}$ & $\begin{array}{c}-0.28 \\
\text { NS }\end{array}$ & $\begin{array}{c}-0.88 \\
p=0.002\end{array}$ & 1.00 \\
\hline $\begin{array}{l}\text { 10. Time to } \\
\text { Peak P. } \\
\text { (secs) }\end{array}$ & $\begin{array}{c}-0.18 \\
\text { NS }\end{array}$ & $\begin{array}{l}-0.14 \\
\text { NS }\end{array}$ & $\begin{array}{c}-0.40 \\
\text { NS }\end{array}$ & $\begin{array}{c}-0.30 \\
\text { NS }\end{array}$ & $\begin{array}{c}-0.15 \\
\text { NS }\end{array}$ & $\begin{array}{l}0.16 \\
\text { NS }\end{array}$ & $\begin{array}{c}-0.27 \\
\text { NS }\end{array}$ & $\begin{array}{c}-0.19 \\
\text { NS }\end{array}$ & $\begin{array}{c}-0.01 \\
\text { NS }\end{array}$ \\
\hline
\end{tabular}


TABLE III

Zero Order Correlation Coefficients between Variables in this Study, Club Level Rowers (n = 8)

\begin{tabular}{|c|c|c|c|c|c|c|c|c|c|}
\hline Variables & 1 & 2 & 3 & 4 & 5 & 6 & 7 & 8 & 9 \\
\hline $\begin{array}{l}\text { 1. Upper Body } \\
\text { Strength } \\
\text { (kg) }\end{array}$ & 1.00 & & & & & & & & \\
\hline $\begin{array}{l}\text { 2. Mean Power } \\
\text { (W) }\end{array}$ & $\begin{array}{l}0.37 \\
\text { NS }\end{array}$ & 1.00 & & & & & & & \\
\hline $\begin{array}{l}\text { 3. Peak Power } \\
\text { (W) }\end{array}$ & $\begin{aligned} & 0.58 \\
p= & 0.009\end{aligned}$ & $\begin{aligned} & 0.90 \\
p= & 0.001\end{aligned}$ & 1.00 & & & & & & \\
\hline $\begin{array}{l}\text { 4. Minimum } \\
\text { Power } \\
\text { (W) }\end{array}$ & $\begin{array}{l}0.18 \\
\text { NS }\end{array}$ & $p=0.001$ & $p=0.59$ & 1.00 & & & & & \\
\hline $\begin{array}{l}\text { 5. Power } \\
\text { Difference } \\
\text { (W) }\end{array}$ & $\begin{array}{l}0.29 \\
\text { NS }\end{array}$ & $\begin{array}{l}0.26 \\
\text { NS }\end{array}$ & $p=\begin{array}{r}0.43 \\
0.04\end{array}$ & $\begin{array}{r}-0.1 \\
\text { NS }\end{array}$ & 1.00 & & & & \\
\hline $\begin{array}{l}\text { 6. Mean Power } \\
\text { (W.kg-1) }\end{array}$ & $\begin{array}{r}-0.1 \\
\text { NS }\end{array}$ & $\begin{aligned} & 0.80 \\
p= & 0.001\end{aligned}$ & $\begin{array}{r}0.66 \\
p=0.02\end{array}$ & $\begin{array}{c}0.69 \\
p=0.002\end{array}$ & $\begin{array}{l}0.14 \\
\text { NS }\end{array}$ & 1.00 & & & \\
\hline $\begin{array}{l}\text { 7. Peak Power } \\
\left(W \cdot \mathbf{k g}^{-1}\right)\end{array}$ & $\begin{array}{l}0.15 \\
\text { NS }\end{array}$ & $\begin{aligned} & 0.70 \\
p= & 0.001\end{aligned}$ & $\begin{array}{r}0.80 \\
p=0.00\end{array}$ & $\begin{array}{r}0.51 \\
p=0.02\end{array}$ & $\begin{array}{l}0.37 \\
\text { NS }\end{array}$ & $\begin{array}{r}0.84 \\
p=0.001\end{array}$ & 1.00 & & \\
\hline $\begin{array}{l}\text { 8. Minimum } \\
\text { Power } \\
\text { (W.kg-1) }\end{array}$ & $\begin{array}{c}-0.20 \\
\text { NS }\end{array}$ & $\begin{array}{l}0.47 \\
0.03\end{array}$ & $\begin{array}{l}0.31 \\
\text { NS }\end{array}$ & $\begin{array}{r}0.87 \\
p=0.00\end{array}$ & $\begin{array}{c}-0.28 \\
\text { NS }\end{array}$ & $\begin{array}{r}0.71 \\
p=0.001\end{array}$ & $p=\begin{array}{r}0.52 \\
0.01\end{array}$ & 1.00 & \\
\hline $\begin{array}{l}\text { 9. Power } \\
\text { Decline } \\
\text { (\% of Peak P) }\end{array}$ & $\begin{array}{l}0.04 \\
\text { NS }\end{array}$ & $\begin{array}{c}-0.21 \\
\text { NS }\end{array}$ & $\begin{array}{c}-0.06 \\
\text { NS }\end{array}$ & $\begin{array}{c}-0.50 \\
p=0.023\end{array}$ & $\begin{array}{c}0.86 \\
p=0.001\end{array}$ & $\begin{array}{c}-0.23 \\
\text { NS }\end{array}$ & $\begin{array}{l}-0.03 \\
\text { NS }\end{array}$ & $\begin{array}{c}-0.52 \\
p=0.01\end{array}$ & 1.00 \\
\hline $\begin{array}{l}\text { 10. Time to } \\
\text { Peak P. } \\
\text { (secs) }\end{array}$ & $\begin{array}{c}-0.02 \\
\text { NS }\end{array}$ & $\begin{array}{r}0.21 \\
\text { NS }\end{array}$ & $\begin{array}{l}0.06 \\
\text { NS }\end{array}$ & $\begin{array}{r}0.47 \\
p=0.03\end{array}$ & $\begin{array}{l}-0.40 \\
\text { NS }\end{array}$ & $\begin{array}{l}0.08 \\
\text { NS }\end{array}$ & $\begin{array}{c}-0.11 \\
\text { NS }\end{array}$ & $\begin{array}{l}0.36 \\
\text { NS }\end{array}$ & $\begin{array}{r}-0.47 \\
p=0.03\end{array}$ \\
\hline
\end{tabular}

TABLE IV

Differences in all the Variables between the Elite Rowers and the Club Rowers

\begin{tabular}{|c|c|c|c|c|c|c|c|c|}
\hline Variables & $\begin{array}{l}\text { Age } \\
\text { (yrs) }\end{array}$ & $\begin{array}{l}\text { Height } \\
\text { (cm) }\end{array}$ & $\begin{array}{l}\text { Weight } \\
\text { (kg) }\end{array}$ & $\begin{array}{c}\text { Body } \\
\text { Fat } \\
(\%)\end{array}$ & $\begin{array}{l}\text { LBW } \\
\text { (kg) }\end{array}$ & $\begin{array}{l}\text { Upper } \\
\text { Body } \\
\text { Strength } \\
\text { (kg) }\end{array}$ & $\begin{array}{l}\text { Mean } \\
\text { Power } \\
\text { (W) }\end{array}$ & $\begin{array}{l}\text { Peak } \\
\text { Power } \\
\text { (W) }\end{array}$ \\
\hline \multirow[t]{2}{*}{ ANOVA } & NS & $p<0.003$ & $p<0.001$ & NS & $p<0.001$ & $p<0.001$ & $p<0.001$ & $p<0.001$ \\
\hline & & $F=10.97$ & $F=13.81$ & & $F=18.21$ & $F=40.06$ & $F=64.53$ & $F=60.37$ \\
\hline Variables & $\begin{array}{l}\text { Min. } \\
\text { Power } \\
\text { (W) }\end{array}$ & $\begin{array}{c}\text { Power } \\
\text { Difference } \\
\text { (W) }\end{array}$ & $\begin{array}{c}\text { Mean } \\
\text { Power } \\
\left(\mathbf{W} \cdot \mathbf{k g}^{-1}\right)\end{array}$ & $\begin{array}{c}\text { Peak } \\
\text { Power } \\
\left(W . \mathbf{k g}^{-1}\right)\end{array}$ & $\begin{array}{c}\text { Min. } \\
\text { Power } \\
\left(W . \mathbf{k g}^{-1}\right)\end{array}$ & $\begin{array}{l}\text { Power } \\
\text { Decline } \\
(\%)\end{array}$ & $\begin{array}{l}\text { Time to } \\
\text { Peak } \\
\text { Power }\end{array}$ & \\
\hline \multirow[t]{2}{*}{ ANOVA } & $p<0.001$ & $p<0.001$ & $p<0.001$ & $p<0.001$ & $p<0.001$ & NS & NS & \\
\hline & $F=30.07$ & $F=19.13$ & $F=57.22$ & $F=56.48$ & $F=20.57$ & & & \\
\hline
\end{tabular}

regarding the variables used in this study. The ER produced significantly higher scores for both the DAAWT and the upper body strength measurements than the CR.

Stepwise Discriminant Analysis revealed one significant discriminant function ( $<<0.001$; Wilk's Lambda $=0.220$; Chi-Squared $(2)=31.71$ ) containing two variables: mean power and power difference expressed in Watts. These variables - accounted for $74 \%$ of the variance between the two groups - were chosen out of the nine DAAWT variables included in the Discriminant Analysis. The problems of multi-colinearity of variables in multiple discriminant analysis have been discussed (Frank et al, 1965). It was felt, however, that the inclusion of all nine variables would give a better picture of their discriminator validity, despite the high intercorrelations.

\section{DISCUSSION}

Upper Body Strength. The present results show a fairly high correlation between mean power output and upper body strength in the ER ( $r=0.81$, Table II) which agrees with the findings of Ayalon et al (1974), who have shown that strength correlates well with the performance of a complex anaerobic activity. The lack of a reasonably high correlation between strength and peak power is noteworthy $(r=0.55$, $p>0.05)$.

Double Arm Anaerobic Work Test. The predominance of significant correlations in Tables II and III indicates that these measures reflect some common aspects of anaerobic ability. The absence of any statistical difference regarding the time to peak power between the two groups (Table IV) together with the non-significant correlation coefficients 
(Tables II and III), probably arises from the repetitive nature of rowing, where in contrast to "instantaneous" events such as throwing and jumping, rowers are not specifically trained to produce such explosive power outputs. On the other hand, there are large differences between the two groups $(0.05>p>0.001)$, when the obtained peak, mean, and minimum power scores were statistically tested (Table IV). This is a fairly good indication of the importance of anaerobic metabolism for rowing excellence. With the same body weight percentage $(8 \%)$ for both groups being used to calculate the work load, ER rowers performed considerably better for all three variables (Table I). When these scores are adjusted for body weight, the significant differences are still maintained but with lower $F$ values (Table IV).

The results of the multiple discriminant analyses indicate that two DAAWT variables (average power and power difference expressed in Watts) were sensitive enough to discriminate and correctly classify $91.8 \%(p<0.001)$ of the subjects tested into their respective groups. The failure of peak power to meet the criteria set $(p<0.05$, Tolerance $=$ 0.3) for the final discriminant analysis, resulted in its exclusion from the final variable selection. This strengthens the belief that very high peak power values may be less important in rowing probably due again to the repetitive and prolonged nature of the sport.

Power decline is closely related to muscular fatigue. In the present study, the decline of power output (from peak to minimum power) during the DAAWT was marked for both groups (Table 1). The significant negative correlation coefficients of this study (Table II, ER) partly reinforce previous work on women rowers, suggesting that the strongest rowers show the least fatigue (Clarkson et al, 1984). This was not, however, the case in the CR (Table III). Additionally, the present data failed to confirm the observations concerning fatiguability when power difference, expressed as a percentage relative to peak power, was tested for significance between the two groups. The revealed non-significant difference (Table IV) may possibly be explained by the fact that, in both groups, the training process has improved motor skill optimisation of muscle function, in such a way as to minimise the tendency to develop fatigue during movements that are closely related to actual rowing. Finally, within the DAAWT neither peak nor mean power (normalised for body weight) correlated with power decrease, in agreement with other workers (Inbar et al, 1981; Goslin and Graham, 1985). Factors which have not been investigated here, such as the enzyme characteristics of muscle fibre types, may account for this finding.

In conclusion, the present data suggests that the present modified version of the original Wingate Test is a reasonably good method for gaining information regarding the upper body short term work ability of junior oarsmen. It provides sensitive indices, particularly if expressed as absolute values, for differentiation between elite and club level junior rowers. Furthermore, the data also demonstrate that the strongest elite rowers show the least fatigue and are capable of producing the highest mean power outputs.

\section{References}

Ayalon, A., Inbar, O. and Bar-Or, O., 1974 "Relationships among measurements of explosive strength and anaerobic power". In Nelson, R. and Morehouse, C. (eds.): Int. Series in Sports Sci. Vol. 1, Biomechanics IV. Baltimore Univ. Park Press, pp. 572-577.

Bar-Or, O., 1978 "A new anaerobic capacity test - characteristics and applications". Proc. 21st World Cong. Sports Med., Brasilia, Sept. 7-12.

Bar-Or, O., Dotan, R. and Inbar, O., 1977 "A 30-sec. all-out ergometric test: its reliability and validity for anaerobic capacity". Israel J. Medical Sci. 13: 326.

Clarkson, P. M., Graves, J., Melchionda, A. M. and Johnson, J., 1984 "Isokinetic strength and endurance and muscle fiber type of elite oarswomen". Can.J.Appl.Sport Sci. 9: 127-132.

Dotan, R. and Bar-Or, O., 1983 "Load optimization for the Wingate anaerobic test". Eur.J.Appl.Physiol. 51: 409-417.

Durnin, J. V. G. A. and Rahaman, M. M., 1967 "The assessment of the amount of fat in the human body from measurements of skinfold thickness". Brit.J.Nutr. 21: 681-689.

Frank, F. E., Massy, W. F. and Morrison, D. G., 1965 "Bias in multiple discriminant analysis". J.Marceting Res. 3: 190-194.

Goslin, B. R. and Graham, T. E., 1983 "A comparison of "anaerobic" components of oxygen debt and the Wingate test". Can.J.Appl. Sport Sci. 10: 134-140.

Hagerman, F. C., 1984 "Applied physiology of rowing". Sports Med. 1: 303-326.

Hagerman, F. C., Hagerman, G. R. and Mickelson, T. C., 1979 "Physiological profiles of elite rowers". Phys.Sports Med. 7: 74-81.

Hagerman, F. C. and Staron, R. S., 1983 "Seasonal variations among physiological variables in elite oarsmen". Can.J.Appl.Sport Sci. 8: 143-148.

Inbar, O., Kaiser, P. and Tesch, P., 1981 "Relationships between leg muscle fiber type distribution and leg exercise performance". Int.J.Sports Med. 2: 154-159.

Jackson, R. C. and Secher, N. H., 1976 "The aerobic demands of rowing in two Olympic rowers". Med.Sci.Sports 8: 168-170.

Jacobs, I., Bar-Or, O., Dotan, R., Karlsson, J. and Tesch, P., 1983. “Changes in muscle ATP, CP, Glycogen and Lactate after performance of the Wingate anaerobic test". In: Knuttgen, H., Vogel, J. and Poortmans, J. (eds.), Biochemistry of exercise, pp. 234-238. Human Kinetic Publishers Champaign.

Mahler, D. A., Andersen, D. C., Parker, H. W., Mitchell, W. S. and Hagerman, F. C., 1983 "Physiologic comparison of rowing performance between National and Collegiate women rowers". Med.Sci.Sports Exerc. 15: 158-158.

Mahler, D. A., Parker, H. W. and Andersen, D. C., 1985 "Physiologic changes in rowing performance associated with training in Collegiate women rowers". Int.J.Sports Med. 6: 229-233.

Nie, N. H., Hull, C. H., Jenkins, J. G., Steinbrenner,K. and Bent, D. H., 1975 "Statistical package for the social sciences". McGraw-Hill, N.Y., 2nd ed.

Secher, N.H., 1983 "The physiology of rowing". J.Sports Sci. 1: 23-53.

Secher, N. H., Espersen, M., Binkhorst, R. A., Andersen, P. A. and Rube, N., 1982 "Aerobic power at the onset maximal exercise". Scand.J.Sports Sci. 4: 12-16.

Sharp, N. C. C., Koutedakis, Y., Slater, T., Harris, G. and Katsikas, F., 1986 "A test of anaerobic capacity of the upper body". Scot.J.Phys.Educ. 14: 4-10.

Tamayo, M., Susec, A., Phillips, W., Bucno, M., Laubach, L. and Frey, M., 1984 "The Wingate anaerobic power test, peak blood lactate and maximum oxygen debt in elite volleyball players: a validation study". Med.Sci.Sports Exerc. 16: 126.

Tharp, G. D., Newhouse, R. K., Uffelman, L., Thorland, W. G. and Johnson, G. $0 ., 1985$ "Comparison of sprint and run times with performance on the Wingate Anaerobic Test". Res. Quart. 56: 73-76. 